Click www.researchjournal.co.in/online/subdetail.html to purchase.

A

\section{Research Aвтіcle: Biological compatibility of spinetoram with selected agro-chemicals against sucking pests, foliar diseases and natural enemies in Bt cotton ecosystem}

\author{
B. RAJASEKAR, C.P. MALLAPUR AND V. SUNIL
}

Article Chronicle:

Received :

15.07.2017;

Accepted :

30.07.2017

KeY Words:

Bioefficacy,

Combinations,

Spinetoram 12 SC,

Sucking pests,

Diseases, Cotton

Author for correspondence :

\section{B. RAJASEKAR}

Department of

Agricultural

Entomology, University

of Agricultural Sciences,

DHARWAD (KARNATAKA)

INDIA

Email :

rajashekarbontha09@

gmail.com

See end of the article for

authors' affiliations
SUMMARY : A field trial was conducted to evaluate the bioefficacy of combinations of spinetoram 12 SC with fungicides / fertilizer / growth regulator, as foliar application on 90 days old Bt cotton against sucking pests and foliar diseases. The lowest mean population of aphids (3.93 / 3 leaves), leafhoppers (4.20 / 3 leaves), thrips (3.01 / 3 leaves), whiteflies (1.09/ 3 leaves) and mirid bugs ( 1.67 / five squares) were recorded in spinetoram $12 \mathrm{SC} @ 1 \mathrm{ml}$ + carbendazim 50WP @ $1.0 \mathrm{~g}$ with $(64.99,63.00,83.60,82.82$ and 50.35) high per cent reduction over control, respectively. Treatments, spinetoram in combination with carbendazim and copper oxychloride were recorded high per cent disease over control (34.05 and 30.87) for Alternaria blight and Bacterial blight, respectively. Spinetoram in combination with carbendazim and copper oxychloride were found to be more effective in reducing the sucking pests population and foliar diseases incidence, and safer to the three natural enemies (coccinellids, chrysopids and spiders) in cotton crop.

How to cite this article : Rajasekar, B., Mallapur, C.P. and Sunil, V. (2017). Biological compatibility of spinetoram with selected agro-chemicals against sucking pests, foliar diseases and natural enemies in Bt cotton ecosystem . Agric. Update, 12(TECHSEAR-5) : 1405-1409; DOI: 10.15740/HAS/AU/12.TECHSEAR(5)2017/ 1405-1409. 